\title{
Communicative Strategy Issues in Foreign Language Professional Training of Bachelor's Degree Programme at Non-Linguistic University
}

\author{
Alexandra V. GLOTOVA \\ Senior Lecturer \\ Foreign languages department \\ Lomonosov Moscow State University Branch in Sevastopol \\ 7, Geroev Sevastopolya str., Sevastopol, 299001, the Russian Federation \\ $+79787692488$ \\ glotova@glotova.com \\ Mariya A. ZUBKOVA \\ Senior Lecturer \\ Foreign languages department \\ Institute of Social Sciences and International Relations \\ Sevastopol State University \\ 33, Universitetskaya str., Sevastopol, 299001, the Russian Federation \\ $+79787273530$ \\ $\underline{\text { m.a.zubkova@gmail.com }}$
}

\begin{abstract}
The article considers the problem of communicative strategy formation which defines the structure, principles, approaches, teaching methods, forms and types of activities in the process of foreign language professional training of bachelors at non-linguistic universities. The authors analyse the existing interpretations of the concepts of 'communicative strategy', 'communicative and information competency', 'communication' and 'foreign language communicative culture'. The paper presents the fundamental principles of communicative strategy planning and describes the optimal methods and approaches to foreign language teaching at non-linguistic institutions of higher education in the city of Sevastopol. The research comprises the results of pedagogical study in foreign language teaching of bachelors of non-linguistic majors on the basis of Lomonosov Moscow State University Branch in Sevastopol and Institute of Social Sciences and International Relations of Sevastopol State University.
\end{abstract}


The key components of communicative and information competency are identified. Communication strategy is worked out according to the peculiarities and features that should be taken into account when planning the process of foreign language teaching of bachelors. The authors consider the specifics of foreign language professional training planning of bachelors at non-linguistic university in the context of the implementation of the Federal State Educational Standard of Higher Education of the new generation. The necessity to focus on the aspects of foreign language professional training considering fundamental objectives, tasks, outcomes and learning needs of bachelors is emphasized. The vital skills needed for successful communication in the professional field at the international level are described.

Keywords: communication strategy; foreign language professional training; communicative and information competency; foreign language communicative culture; non-linguistic university.

\section{Introduction}

The Foreign Language Discipline is considered mandatory in the context of basic educational programmes of undergraduate studies at non-linguistic universities. Learning a foreign language and its various aspects is a prerequisite for providing high-quality professionally oriented training for undergraduate students in all areas, since professionally oriented training is aimed at meeting the needs of a future specialist in learning a foreign language depending on the specifics of his or her future scope of activity.

The skills and abilities acquired during subject mastery become the basis of communication in a foreign language of students in academic environment and future professional activities at an international level. The Foreign Language Discipline contributes to the formation of basic universal competencies of undergraduate students of technical, humanitarian and natural science training programmes at non-linguistic university according to the requirements of the current Federal State Educational Standards of Higher Education (FSES of HE) (The Federal State Educational Standard of Higher Education for Bachelor's degree programmes).

The essence and content of a professionally oriented foreign language bachelor's training may vary depending on the characteristics of an educational programme and curriculum. However, the fundamental goal of training students of all majors at non-linguistic university is to teach various types of communication in a foreign language. Moreover, the professionally oriented foreign language bachelor's training is partially aimed at the formation of related universal competencies: systemic and critical thinking, development and implementation of projects, teamwork and 
leadership, intercultural interaction, self-organization and self-development (Krupkin, Sinyakova, 2020; Sale, 2020).

At the same time, the content of professional training at a university is regarded as a dynamic field, since it is built considering the latest developments and discoveries in a particular area. Foreign language mastery helps receive and transmit the most relevant information in a professional environment and integrate successfully into the labour market (Vintere, Ozola, Krumina, 2019). Consequently, one should pay attention to the relevance of developing a communicative strategy, which in our study is a set of measures and tactics for setting foreign language training. The right choice of a communicative strategy considers the current educational trends, the specifics and needs of students, as well as the features of a professionally oriented training of bachelors at non-linguistic university.

This work is devoted to the problem of forming a communicative strategy that defines the structure, principles, approaches, teaching methods, forms and types of activity as part of the professionally oriented foreign language bachelor's training at non-linguistic universities.

\section{Methods}

The study is based on the results of pedagogical observation when teaching bachelors of nonlinguistic training programmes based on the branch of Lomonosov Moscow State University in Sevastopol and the Institute of Social Sciences and International Relations of Sevastopol State University (ISSIR of SevSU). Synthesis and analysis of regulatory documents governing the activities of educational institutions in the System of Higher Education in Russia (FSES of HE, the Federal Law 'On Education in the Russian Federation' No. 273-Ф3, implementation provisions) have been carried out (The Federal Law 'On Education in the Russian Federation', 2012; The Regulation on e-learning and distance learning technologies, 2018). Systematization of the data obtained from Russian and foreign scientific research has been performed.

Review of literature: The analysis of scientific pedagogical literature shows that a substantial theoretical base has been developed, including works and publications on the setting of professionally oriented teaching of a foreign language in the higher education system: Andreeva (2016), Cheng (2019), Hyland (2019), Krupchenko (2016), Lapteva (2019), Li (2019), Sakharova, Tenishcheva, Ter-Minasova.

In the presented study, the concept of 'communicative strategy' is considered as a key component of the methodology of a professionally oriented foreign language bachelor's training at nonlinguistic university. The definition of the content of a communicative strategy as part of this work is directly related to the goals and objectives of a foreign language teaching, principles, choice of 
approaches, methods and means of teaching foreign language communication. Thus, the term is defined from the point of view of goalsetting. We should note that the concept of 'communicative strategy' is not new and has a broad interpretation in various areas of science (Pangaribuan et al., 2020; Rabab'ah, 2016; Ruler, Körver, 2018). Summarizing various formulations of the term in question, Kravets (2013) analyses the works by Alstrand, Lempel, Mintzberg, Orlova and others, where the main emphasis is on the definition of the concept 'strategy' as: '... a plan, principle for conduct, position, perspective, technique'.

On the other hand, the term 'communicative strategy' is identified in scientific publications with the concept 'pedagogical discourse' - a set of vocal acts or verbal behaviour aimed at achieving a communicative goal or impact on the recipient (Borisova, Issers, Pospelova, Sorokina) (Dryangina, 2017).

Muravyova (2007) believes that a communicative strategy is 'a kind of communicative plan that involves certain communicative goals'.

Communicative strategy is viewed by Malyuga and Tonvilin (2017) as "a part of communicative behaviour or communicative interaction, in which variable verbal and non-verbal means are used to achieve a specific communicative goal while taking into account the communicative setting and personal characteristics of communicating entities involved in the process".

Sorokina (2014) considers a communicative strategy as 'a complex of vocal acts aimed at achieving a global communicative goal', emphasizing that these acts depend not only on the personality of the interlocutors, but also on the conditions and relationships between them.

Mikhaylina (2017) notes that a communicative strategy is necessary during communication in a foreign language to capture the information of interest expressed by the interlocutor and to express our attitude to it, using general mechanisms for receiving and transmitting information.

According to Makarov (1998), 'a communicative strategy' is 'a type or line of behaviour of one of the interlocutors in a specific communicative situation that correlates with the plan to achieve predominantly global (sometimes a number of local) communication goals'.

Cornelissen (2004) considers communicative strategy not only as a choice of basic communication strategy, but also as a specific plan of strategic actions, namely, setting communicative goals, determining target audiences and means of communication, as well as directly communicating.

Subsequently, in this study, a communicative strategy is not only a plan to implement a professionally oriented foreign language bachelor's training at non-linguistic university, but also a 
system of communicative interaction and cooperation of the parties in the educational process when teaching a foreign language.

To carry out communication in a foreign language, bachelors, both of humanitarian and technical training programmes, need to master not only the basic lexical and grammatical material, but also various skills and abilities of a higher level (Serova, Perlova, Pipchenko, Chervenko, 2020). Among the most demanded skills of the $21^{\text {st }}$ century and key competences for lifelong learning, researchers note the following: critical thinking, problem solving, intercultural communicative competence, skills and methods of organizing and conducting research, innovation, leadership, creativity, initiative, communication, cooperation, collaboration, media literacy, cultural and global awareness, flexibility in learning, and others (Annex to Proposal for a Council Recommendations on Key Competences for Lifelong Learning, 2018; Beers, 2016; Kennedy, Sundberg, 2020; Scott, 2015; Shimichev, 2020; Towards Defining 21st Century Competencies. The Foundation Document for Discussion, Ontario, 2016; Tran, Seepho, 2016).

Therefore, while mastering the Foreign Language Discipline, a future specialist should build a professional thesaurus, as well as acquire a set of skills, abilities, universal and professional competencies that promote interpersonal and intercultural interaction.

Moreover, the communication process of students at non-linguistic university is inherently linked with various types and methods of working with information in a foreign language. The professionally oriented foreign language bachelor's training involves teaching students to work with authentic information resources and materials directly related to their major. As a result, the Foreign Language Discipline, being a diverse and complex educational product with a clear professional focus, contributes to the formation of a 'communicative and information competency'. The presented competency is a key component in the development of a communication strategy for foreign language bachelor's training.

To date, there is no single definition of the concept 'communicative and information competency'. Basically, scientific works examine the term 'communicative and information competence', which is based on the skills and abilities of organizing professional activities using information and communication technologies (ICTs). Rak (2017) generalizes the concept of competency as '... an aspect of the social adaptation of an individual in an information-communication developed society' and draws attention to the existence of a different approach to the definition of the term 'communicative and information competence', which is based on two components: information and communication. The process of 'perceiving information by a subject through a communicative act, an action with various information in professional and practical activities' is directly considered. 
It should be noted that among Russian researchers (Burmakina, Falina, Elizarov and others) there is a tendency not to separate the concepts of 'communicative and information competence' and 'communicative and information competency'. However, in this work it is advisable to draw a line between these key logical concepts. In this study, the specific concept of 'competency' is considered in the generally accepted pedagogical sense as an integrated learning outcome, including the willingness to apply the acquired knowledge, skills and abilities in professional activities (Rak, 2017). It is the determination of the spectrum of necessary knowledge, skills and abilities, as well as the specifics of the process of their acquisition, that are considered when developing a communicative strategy for professionally oriented foreign language training of bachelors of nonlinguistic universities. Let us point out that the term 'competency' in our work is a broader concept, considered as an already formed quality of a future specialist acquired through personal experience, a criterion for his or her accomplishment, characterized by systematic knowledge and thinking.

Development of a communicative strategy is based on the planned and expected results of teaching a foreign language at non-linguistic university. Moreover, considering the provisions of Russian Digital Economy Programme, development of the communicative and information competency is a priority for professional training of bachelors (Passport of the national programme "Digital Economy of the Russian Federation", 2018).

Next, we will consider the components of the 'communicative and information competency', which determine the features of a communicative strategy of a professionally oriented foreign language training of bachelors.

\section{Results}

The communicative and information competency in the analysed study is a comprehensive concept, which includes mastering of various types of communication in professional activities, skills and abilities to work with information in a foreign language, as well as skills in using ICTs and other educational online technologies in professional activities.

Among the key components of the communicative and information competency, it is necessary to single out the following building blocks that should be paid attention to when developing a communicative strategy:

- understanding of the subject and terminology of the professional sphere in a foreign language (mastery of a professional thesaurus);

- ability to carry out business communication in oral and written form in a foreign language (knowledge of grammar, speech etiquette formulas in various communicative situations); 
- acquisition of skills to work with authentic sources of information (mass media texts, analytical and scientific publications: analysis, structuring, and presentation);

- skills and abilities to organize and conduct research using literature in a foreign language (taking notes, summarizing, writing talking points);

- skills and abilities to search for information in a foreign language in printed and digital sources of information (reading for specific information, reading for detail, skimming and scanning);

- setting of cognitive activities using ICT (extraction and processing of information according to the goal);

- skills and abilities to prepare presentations and publications containing the results of research in a foreign language (to highlight problems, to consider their aspects, to state the main points briefly and logically, to justify and give reasons for your position, to give examples, to summarize the results, to be able to isolate information according to the communicative tasks).

The process of a professionally oriented foreign language training is aimed at the development of a 'foreign language communicative culture' of bachelors at non-linguistic university, which includes a range of skills, abilities and competencies acquired when mastering the Foreign Language Discipline.

However, it is necessary to highlight the importance of communicative culture as the final educational product that combines two important semantic concepts: 'communication' and 'culture', which underlie the development of a communicative strategy. Next, let us analyse the content of these interconnected components.

One of the meanings of the term 'communication' (from Latin 'communico' - to make something common, to connect, to communicate) given by the thesaurus is communication, transfer of information from one person to another (a specific form of interaction between people in the process of cognitive and labour activity, which is carried out mainly using a language (less often using other sign systems)) (Online Thesaurus).

The term 'culture' (from Latin 'cultura' - cultivation, upbringing, education, development, veneration) is a historically defined level of social development, the creative forces and abilities of a person, expressed in types and forms of organization of people's life and activities, in their relationships, as well as in the material and spiritual values they create (Online Thesaurus).

In the scientific literature, there is a clear connection between culture and communication, since the transfer of human achievements to succeeding generations is possible only through certain channels 
of information transfer, and, vice versa, scientific and technological progress, industrial and spiritual development of society is impossible without effective communication between society members.

The concept of 'communicative culture' is a complex phenomenon and is interdisciplinary in nature, as it is widely used in linguistics, pedagogics, psychology, sociology, philosophy, etc.

In this work, the publications analysing the meaning of the terms in question from a pedagogical point of view are of importance. In the works by Mudrik (1991) this concept is considered as a component of professional culture of a specialist's personality (a set of knowledge, norms, values and behaviour patterns that are accepted in society, and the ability to smoothly and naturally implement them in business and emotional communication).

Stolyarov and Yakushev (1999) interpret the communicative culture as a set of personality traits necessary for establishing cooperation and creating dialogue relationships, as well as presence of a moral and tolerant attitude towards the interlocutor, sympathy and ability to evaluate people objectively.

Aukhadeeva (2008) notes that development and formation of culture and communication are inseparable, culture is communication, and communication is culture; these are two universal social phenomena that form 'communicative culture'.

It should be noted that at present there is also no single interpretation of the concept 'foreign language communicative culture' (FLCC), however, this term in our study is directly related to the concept 'global awareness', which is considered a priority skill of the 21 st century.

Scientists Bim, Nevmerzhitskaya, Passov, Safonova, Furmanova associate FLCC with an individual's ability to learn a foreign language and to communicate in it with representatives of other cultures.

According to Ishkhanyan (1996), FLCC is the ability to choose and implement programmes of foreign verbal behaviour depending on the goals and content of communication, as well as to organize this communication, considering the changing communicative situation, relationships of interlocutors and communicative attitudes, i.e. the command of strategy and tactics of communication.

Kopyova (2006) defines FLCC as 'a combination of knowledge, skills and abilities in the field of communication tools and the laws of interpersonal interaction between representatives of different cultures that contribute to mutual understanding and effective solution of communication problems'. 
Within the framework of our article, we consider the concept of a 'foreign language communicative culture' as a combination of foreign language communicative abilities, knowledge, values, norms, behaviour patterns and professional skills that determine a successful solution of communicative tasks based on sociocultural norms of behaviour.

Among the key features of developing a communicative strategy for professionally oriented foreign language bachelor's training is the right choice of goals, objectives, principles, modern methods, and approaches to teaching a foreign language.

When planning a communicative strategy of a professionally oriented foreign language training of undergraduate students, it is necessary to pay attention to the definition of fundamental principles. Let us consider the most important of them:

1. the principle of compliance of the foreign language teaching content with the requirements of modern society, state, international and professional educational standards (FSES of HE $3++$, Professional Standards, Common European Framework of Reference for Languages (CEFR), the Concept of Open Education, Partnership for $21^{\text {st }}$ Century Skills, Framework for $21^{\text {st }}$ Century Learning);

2. the principle of unity of the substantive and procedural aspects of teaching a foreign language (determines the specifics of building the foreign language training based on the characteristics of curricula and steering documents);

3. the principle of fundamental education of teaching a foreign language (establishment of interdisciplinary ties and integrated perception of the material studied);

4. the principle of compliance of the components of a foreign language teaching content with the structure of the communicative culture of a person;

5. the principle of scientificity in teaching a foreign language (the need to work with authentic sources of scientific literature);

6. the principle of regularity and consistency (a communicative strategy that determines the sequence of presentation of the material and practicing).

Among the most popular and appropriate approaches based on the communicative strategy of setting professionally oriented foreign language training of bachelors of non-linguistic universities, the following should be highlighted:

1. system and activity approach (lies at the heart of FSES of HE development, according to which the entire learning process represents various types of focused activities); 
2. integrated approach (combines diverse types and forms of work aimed at the development of all types of oral activity);

3. facilitation approach (a strategy of partnership interaction and equal cooperation of all parties in the educational process);

4. cultural (implementation of the educational process in cultural environment, in the dialogue of different cultures, recognition of the priority of culture in the educational process);

5. technological approach (typical for non-humanities, allows to systematize, formalize and normalize the educational process);

6. axiological approach (implies formation of a system of humanistic socio-moral value orientations of the personality of a future professional);

7. communicative approach (setting of foreign professional communication of future specialists in an innovative educational environment);

8. environmental approach (ensuring comprehensive socialization and effective adaptation of students in changing socio-economic conditions).

The communicative strategy of foreign language training is also built considering the solution to the problem of choosing the best methods and means of teaching bachelors a foreign language. Among the latest methods, the communicative one is considered a priority, and it is often used as the basic one in planning professionally oriented foreign language training of bachelors at non-linguistic universities of the city of Sevastopol. This method is aimed at a practical mastery of communication skills and abilities in business and professional activities and allows bringing the learning process as close as possible to reality.

The use of the linguosociocultural method contributes to the formation of a communicative culture (i.e., mastery of the basics and the aspects of linguistic and intercultural communication).

In the process of professionally oriented foreign language training, as part of the communicative strategy development, it is necessary to integrate popular active teaching methods aimed at enhancing students' educational, cognitive and research activities: business and role-playing games, thematic discussions, project activities, case technologies, web-quest technology (Web Quest), a case study method, etc.

Planning a communicative strategy for a professionally oriented foreign language bachelor's training takes into account innovations in the educational process. The capabilities of distance and e-learning (the use of ICTs, online learning, integration of blended learning models) make the 
learning process more flexible and effective. At Sevastopol State University electronic information educational environment on Moodle platform was actively used in foreign language classes in 2018/2019 and is being used in 2019/2020 (Modular Object-Oriented Dynamic Learning Environment) (http://russian_moodle.sevsu.ru/). The resources of this platform allow successfully implementing the provisions and requirements of e-learning a foreign language. A portal for remote assistance (https://distant.sev.msu.ru/) was developed based on the MSU branch to optimize the educational process and to develop independent work skills.

To improve the quality of professionally oriented foreign language training of students in educational institutions of Sevastopol, popular massive open online courses (MOOC) are used, presented on the world's leading educational platforms (Coursera, Stepik, Stanford Online, FutureLearn, Open Education, etc.). The development of steering documents of the Foreign Language Discipline with MOOCs integration allows transforming the format of interaction between the parties to the educational process. Due to this opportunity, students study authentic video materials aimed at the development of a foreign language communicative culture, get acquainted with examples of dialogs and norms of communication, learn to listen and hear, analyse and perceive the opinions of others, take into account the cultural characteristics of representatives of the country of the language being studied, solve professional problems, and build a professional thesaurus.

The practical application of skills and abilities is an integral part of developing a foreign-language communicative culture. Within the framework of the communicative strategy of professionally oriented foreign language training of bachelors of universities, an active involvement of students in various international events, projects and scientific and practical conferences is expected. With this aim, the annual international and All-Russian scientific and practical conferences, forums, seminars and round tables are held in higher educational institutions of Sevastopol: (LinguaNet (2019), Profmarket (2017, 2018), 'Lomonosov Readings, Black Sea Conference', Science Festival NAUKA $0+$ etc.).

\section{Discussion}

The process of planning and developing a communication strategy is time-consuming, since it is necessary to consider the specifics of the content of a foreign language teaching depending on the chosen training programme, as well as to focus on the planning aspects of the foreign language teaching process. The presence of a communicative strategy leads to a clear understanding and presentation of a sequence of actions aimed at the effective process of professionally oriented foreign language training of bachelors. Thus, mastering a foreign language implies an ability and 
willingness to communicate at the international level. Moreover, verbal situations of communication in a foreign language, knowledge of the basics of intercultural literacy and professional communicative behaviour contribute to the formation of a foreign language communicative culture. We shall emphasize the fact that information and communication competency is one of the key components of a foreign language communicative culture. The competency under consideration is aimed not only at developing skills in working with information and using ICTs, but also at successfully solving communicative tasks in professional activities.

\section{Conclusion}

The article discusses the essence and content of the concept 'communication strategy of a professionally oriented foreign language training of bachelors at non-linguistic university'. The features that should be considered when planning the process of foreign language teaching of undergraduate students are highlighted. The key components, goals and objectives, principles, approaches, methods and possible forms of interaction between the parties when developing a communicative strategy at non-linguistic university are analysed.

Summarizing the above, we shall emphasize that the correct choice and planning of a communicative strategy as an integrated concept lies at the heart of an effective professionally oriented foreign language training of bachelors at non-linguistic university.

Studying the Foreign Language Discipline contributes to the formation of a wide range of necessary skills, abilities, general and professional competencies aimed at improving the quality of training of qualified personnel for work at the international level.

A future specialist, regardless of his or her training programme and professional activity, should be tolerant of the world outlook of representatives of other cultures, be aware of the rights of cultural diversity, understand responsibility and show respect to representatives of other cultures.

However, this work does not reveal all the issues of the problem under consideration. Our further scientific inquiries and promising areas of research will be devoted to the conduct of a pedagogical experiment aimed at diagnosing the effectiveness of a communicative strategy of professionally oriented foreign language training in the context of modernization of the higher education system of the Russian Federation (taking into account the requirements of the Federal State Educational Standard of the new generation, the Russian Digital Economy Programme, the requirements of modern society and students).

\section{Acknowledgements}


The article uses materials obtained at the departments of foreign languages of the branch of

Lomonosov Moscow State University in Sevastopol and the Institute of Social Sciences and International Relations of Sevastopol State University. The authors would like to thank students and colleagues for their help in conducting the research and their active discussion of the problem under study.

\section{References}

Andreeva, I. (2016). Teaching Culture through Social Situations in English as a Second Language Classes. Master's Projects and Capstones, 330. Retrieved from: https://repository.usfca.edu/capstone/330

Annex to Proposal for a Council Recommendations on Key Competences for Lifelong Learning. (2018). A European Reference Framework. Retrieved from: https://eurlex.europa.eu/resource.html?uri=cellar:395443f6-fb6d-11e7-b8f5$\underline{\text { 01aa75ed71a1.0001.02/DOC_2\&format=PDF }}$

Aukhadeeva, L.A. (2008). The formation of the communicative culture of a modern teacher in the process of university preparation. Extended abstract of Doctor's thesis. Kazan.

Beers, S. (2016). 21st century skills: Preparing students for their future. 21st Century Skills, 1-6. ASCD. Retrieved from: https://cosee.umaine.edu/files/coseeos/21st_century_skills.pdf

Cheng, Y. (2019). Paths to improve the language communicative competence and accomplishment for foreign language professional students. 3rd International Proceedings on Conference on Economics, Management Engineering and Education Technology, 22982302.

Retrieved

from: https://webofproceedings.org/proceedings_series/ESSP/ICEMEET\%202019/ICEMEET1945 8.pdf

Cornelissen, J. (2004). Corporate Communications: theory and Practice. London: SAGE Publications.

Dryangina, Y.A. (2017). Communicative strategies in the pedagogic discourse: the overview of works. Scientific Journal of KubSAU, 131(07). Retrieved from: https://e.mail.ru/attach/15793836511492905027/0\%3B0/?folder-id=0\&xemail=beaty\%40inbox.ru

Hyland, K. (2019). English for Specific Purposes: Some Influences and Impacts. In: Gao X. (eds) Second Handbook of English Language Teaching. Springer International 
Handbooks of Education, 337-353. Retrieved from: https://doi.org/10.1007/978-3-030$\underline{02899-2 \_19}$

Ishkhanyan, N.B. (1996). Ways of formation of linguosociocultural competency during the intensive course of foreign language training (English language at non-linguistic pedagogical university). Extended abstract of Candidate's thesis.

Kennedy, T.J., Sundberg, C.W. (2020). 21st Century Skills. In: Akpan B., Kennedy T.J. (eds) Science Education in Theory and Practice. Springer Texts in Education, 479-496.

Kopyova, E.A. (2006). Foreign communicative culture formation of future teacher. Extended abstract of Candidate's thesis. Orenburg.

Kravets, M.A. (2013). Communicative strategy: systematization of definitions, approaches to development. VGU Bulletin. Series: Economics and Management, 1, 149-153.

Krupchenko, A.K. et al. (2016). Lingvomethodological and psycho-educational aspects of professionally oriented foreign language teaching at the university. Moscow: Scientific technologies.

Krupkin, A., Sinyakova, M. (2020). Identification of Relevant Interactive Teaching Methods for the Development of Universal Competencies of Future Engineers. Integrating Engineering Education and Humanities for Global Intercultural Perspectives. IEEHGIP 2020. Lecture Notes in Networks and Systems, 131, 652-658. Retrieved from: https://doi.org/10.1007/9783-030-47415-7_69

Lapteva, I.V. et al. (2019). Strategies of continuous foreign language training at higher school in professional interaction of non-linguistic specialists. Humanities \& Social Sciences Reviews, 7(4), 103-110. Retrieved from: https://giapjournals.com/index.php/hssr/article/view/hssr.2019.7415

Li, L. (2018). Integrating Technology in ESP: Pedagogical Principles and Practice. Integrating Information and Communication Technologies in English for Specific Purposes. English Language Education, 10, 7-25. Retrieved from: https://doi.org/10.1007/978-3-319$\underline{68926-5 \_2}$

Makarov, M.L. (1998). Interpretative analysis of discourse in a small group. Tver: Tversk State University.

Malyuga, E., Tonvilin, B. (2017). Communicative strategies and tactics of speech manipulation in intcrcultural business discourse. Training, Language and Culture, 1(1), 28-45. Retrieved 
from: $\quad$ https://cyberleninka.ru/article/n/communicative-strategies-and-tactics-of-speechmanipulation-in-intercultural-business-discourse/viewer

Mikhaylina, O.N. (2017). Communicative strategies in the process of forming strategic competency in foreign languages training. ANI: Pedagogics and Psychology, 6, 2(19), 103-105.

Mudrik, A.V. (1991). Socialization and troubled times. Collection.

Muravyova, N.V. (2007). Mechanism and areas of communicative conflicts. Ways to prevent I resolve of communicative conflicts. Communicative strategy and communicative tactics. Communicative code and communicative etiquette. Code and rules. Techniques and language tools. "Language and Conflict". Yekaterinburg: USU. Retrieved from: http://elar.urfu.ru/bitstream/10995/1438/5/1324428_readingbook.pdf

Online Thesaurus. Retrieved from: https://www.vedu.ru/bigencdic/

Pangaribuan, D. et al. (2020). Communication Strategies Used by Teacher. Linguistic, English Education and Art (LEEA) Journal. Retrieved from: https://www.researchgate.net/publication/339320559_Communication_Strategies_Used_by_ $\underline{\text { Teacher }}$

Passport of the national programme "Digital Economy of the Russian Federation". (2018). Approved by the Presidium of the Presidential Council for Strategic Development and National Projects on December 24, 2018. N 16. Retrieved from https://base.garant.ru/72190282/

Rabab'ah, G. (2016). The Effect of Communication Strategy Training on the Development of EFL Learners' Strategic Competence and Oral Communicative Ability. Journal of Psycholinguistic Research, 45, 625-651. Retrieved from: https://doi.org/10.1007/s10936$\underline{015-9365-3}$

Rak, E.V. (2017). The essence of information and communication competency. Scientific notes of Orel State University: humanities and social science, 2(75). Retrieved from: https://cyberleninka.ru/article/n/suschnost-informatsionno-kommunikativnomkompetentnosti

Ruler, B., Körver, F. (2018). The Communication Strategy Handbook: Toolkit for Creating a Winning Strategy. Linguistic English Education and Art (LEEA). Peter Lang Inc., International Academic Publishers. 
Sale, D. (2020) Framing a Curriculum for the Twenty-First Century Competencies. Creative Teachers. Cognitive Science and Technology, 243-262. Retrieved from: https://doi.org/10.1007/978-981-15-3469-0_7

Scott, C.L. (2015). The futures of learning 1: Why must learning content and methods change in the 21st century? United Nations Educational, Scientific, and Cultural Organization Education Research Foresight, 13. Retrieved from: http://unesdoc.unesco.org/images/0023/002348/234807E.pdf

Serova, T., Perlova, I., Pipchenko, E., Chervenko, Y. (2020). Intellect and Intellectual SpeechThinking Activity of Technical University Students in Integrative ProfessionallyOriented Technology of Foreign Language Learning. Integrating Engineering Education and Humanities for Global Intercultural Perspectives. IEEHGIP 2020. Lecture Notes in Networks and Systems, 131. Retrieved from: https://doi.org/10.1007/978-3-030-47415$\underline{7 \quad 42}$

Shimichev, A. (2020). Development of Students' Creative Abilities in Technical University During Foreign Language Training. Integrating Engineering Education and Humanities for Global Intercultural Perspectives. IEEHGIP 2020. Lecture Notes in Networks and Systems, 131, 212-221. Retrieved from: https://doi.org/10.1007/978-3-030-47415-7_22

Sorokina, J.V. (2014). Self-presentation strategy as the basic entity of an effective interaction in pedagogic discourse. Chelyabinsk State University Bulletin, 6(335), 89-92.

Stolyarov, V.I. (2003). Philosophical and culturological analysis of communicative culture. Philosophy issues, 4. 78-91.

The Federal Law 'On Education in the Russian Federation' dated December 29, 2012 N 273-Ф3 (the latest (2012). revision). Retrieved from: http://www.consultant.ru/document/cons_doc_LAW_140174/

The Federal State Educational Standard of Higher Education for Bachelor's degree programmes. Retrieved from: http://fgosvo.ru/fgosvo/92/91/4

The Regulation on e-learning and distance learning technologies (adopted by the decision of the Academic Council of Sevastopol State University dated 23.01.2018. Protocol No. 8). Retrieved from: https://www.sevsu.ru/images/novosti/_2018/02_february/27_02/elearning.pdf 
Towards Defining 21st Century Competencies. The Foundation Document for Discussion, Ontario (2016). Retrieved from: https://edugains.ca/resources21CL/About21stCentury/21CL_21stCenturyCompetencies.pd f

Tran, T.Q., Seepho, S. (2016). An Intercultural Communicative Language Teaching Model for EFL Learners. Retrieved from: https://www.researchgate.net/publication/304086067_An_Intercultural_Communicative_La nguage Teaching_Model_for_EFL_Learners

Vintere, A., Ozola, I., Krumina, S. (2019). Professional foreign language competence for successful integration into the labour market. Society. Integration. Education. Proceedings of the International Scientific Conference, 3, 594-603.

Yakushev, G.I. (1999). To the issue of communicative abilities of teacher personality. Formation of professional identity: problems and prospects, 79-80. 